\title{
Divergent epigenetic profiles from two differentially impacted wild populations of estuarine cordgrass (Sporobolus alterniflorus)
}

\author{
DeCarlo, L., ${ }^{1}$ Meckler, F., ${ }^{1}$ Hans, M., ${ }^{1}$ Kelemen, S., ${ }^{1}$ Magun, H., ${ }^{1}$ Noah, M., ${ }^{1}$ Pappajohn, L., ${ }^{1}$ \\ Anderson, N., ${ }^{1}$ Berger, R., ${ }^{1}$ Berkel, J., ${ }^{1}$ Brooke, N., ${ }^{1}$ Chen, L., ${ }^{1}$ Chijioke, O., ${ }^{1}$ Dewees, N., ${ }^{1}$ \\ Falkner P., ${ }^{1}$ Frank, J., ${ }^{1}$ Holzman, W., ${ }^{1}$ Marino, V., ${ }^{1}$ Ravaschiere, A., ${ }^{1}$ Wang, Y., ${ }^{1}$ Williams, A., ${ }^{1}$ \\ Williams, Z., ${ }^{1}$ Gentile, D., ${ }^{2}$ and Cox, R.L. ${ }^{1,3^{*}}$ \\ ${ }^{1}$ Lisman Laboratories for Molecular Ecology, Riverdale Country School, Bronx, NY, USA \\ ${ }^{2}$ Berkeley Carroll School, Brooklyn, NY, USA \\ ${ }^{3}$ Department of Ecology, Evolution, and Environmental Biology, Columbia University, \\ New York, NY, USA \\ Authors declarations of competing interests: none \\ *Corresponding author. \\ E-mail address: rcox@riverdale.edu (RL Cox).
}

\section{Acknowledgements}

We thank Riverdale Country School, Dominic Randolph and Kelley Nicholson-Flynn for continued support of the Lisman Laboratories. We acknowledge Zachery Halem for his help with planning discussions and analyses. We are grateful to Julia Gardner who assisted with literature searches, and to Travis Brady, Emma Dietz, Juliette Egan, Jacob Katz, Eli Sands, Shae Simpson, and Knut Vanderbush for their invaluable assistance in the laboratory. We thank Melissa Lee and the Harlem DNA Center for donating PCR primers and advice. We thank Dan Luciano who generously shared equipment and expertise.

\section{Author Contributions}

All authors made critical contributions to this study, reviewed drafts, and agree on all aspects of the work. In particular, MH, SK, ND, HM and RLC conceived of, and initiated the heat shock study. LD, FM, MH, SK, HM, MN, NA, RB, NB, JB, LC, RC, ND, PF, BF, WH, LP, AR, YW, $\mathrm{AW}, \mathrm{ZW}$, and RLC designed and executed heat shock experiments. LD, FM, RLC and DG performed final analyses of heat shock data. LD, FM, RLC, MN, JB, LC, OC, RC, BF, DG, WH, VM, LP and WW designed and executed methylation studies. LD, FM, MN, JB, LC, OC, RC, BF, DG, WH, VM, FM, LP and RLC analyzed methylation data. LD, LC, OC, JF, DG, WH, VM and WW designed and executed barcoding experiments. $\mathrm{LD}, \mathrm{OC}$, DG analyzed barcoding data. LD, FM, LP, DG and RLC wrote the manuscript. MN reviewed the manuscript for important intellectual content.

Keywords: \% 5-mC; DNA methylation; ecosystem provider; epigenetic modification; heat shock protein 70 (HSP70); marsh grass; Sporobolus alterniflorus; stress tolerance; urban estuary; wild populations 


\section{Highlights for manuscript submission:}

- estuarine grasses native to the Bronx River, NY face stresses associated with low dissolved oxygen and urbanization

- differentially impacted populations of estuarine grasses exhibit inverse global DNA methylation profiles in response to acute heat stress

- DNA methylation may represent a mechanism by which plants transiently respond to environmental stressors, and this may represent a form of rapid adaptive evolution

- stress priming by transgenerational epigenetic modification may enhance fitness in grasses native to the heavily impacted Bronx River estuary

Abstract

The effects of urbanization on watershed ecosystems present critical challenges to modern survival. Organisms in urbanized areas experience high rates of evolutionary change, but genetic adaptation alone cannot mitigate the rapid and severe effects of urbanization on biodiversity. Highly resilient, foundation species are key to maintaining an ecosystem's integrity in the face of urban stressors. However, the rapid collapse and disappearance of watershed ecosystems calls into question the extent to which we can rely on such species for their services.

62 Our research investigates the molecular mechanisms by which the foundation ecosystems

63 provider, Sporobolus alterniflorus, adapts to life in an urbanized environment. To elucidate these

64 mechanisms, we quantified changes in global DNA methylation (\% 5-mC) as a result of acute

65 heat stress. Specimens from two differentially impacted populations across an urban to suburban

66 geographical transect formed the basis of this study. These two populations of Sporobolus

67 alterniflora exhibit inverse global DNA methylation patterns when exposed to the same acute

68 heat stress. Our findings suggest that epigenetic mechanisms, such as DNA methylation, control

69 rapid and transient adaptation, in the form of differential stress responses, to distinct environment 70 challenges.

1- Introduction

Urban estuaries are highly productive ecosystems that provide critical services including

74 storm surge protection, water filtration and wildlife habitat (Barbier et al., 2011; Franca et al.,

75 2012). Coastal salt marshes comprise approximately $25 \%$ of the global soil carbon sink through 
plant production and high carbon burial rates (Chmura et al., 2003). Human activity, industrialization, and climate change continue to negatively impact estuarine ecosystems, especially in urbanized areas (Limburg et al., 2005; Astaraie-Imani et al., 2012; Chin et al., 2013). Estuarine species face stresses associated with adverse environmental conditions such as low dissolved oxygen, combined sewage overflow, toxin contamination, bank destabilization, habitat degradation, and extreme temperature fluctuation (Van Dolah, et al., 2008; Courrat et al., 2009; Halem et al., 2014; Ravaschiere et al., 2017). Knowledge of the molecular mechanisms underlying stress adaptation is essential if we hope to rehabilitate estuarine ecosystems adversely affected by urbanization.

Urbanization is often associated with rapidly changing anthropogenic stressors (Alberti, 2015; Donihue and Lambert, 2015). As sessile organisms, plants must respond to these environmental challenges by rapidly regulating gene expression, and this is often accomplished via epigenetic alterations such as DNA methylation and histone modification (Arikan et al., 2018; Wang et al., 2010). These transient and rapid modifications provide essential "on demand" phenotypic variation (Rey et al., 2016), that may represent critical adaptive mechanisms for species such as marsh grasses that provide essential ecological services to urban communities.

Here, we take an in vivo approach to the study of epigenetic adaptation in wild populations of smooth cordgrass Sporobolus alterniflorus (formerly Spartina alterniflora), a critical ecosystems provider and foundation species that is native to estuaries throughout the North American east coast (Gedan and Bertness, 2010; Peterson, 2014). This halophyte species is particularly resilient in the face of urbanization (Gedan and Bertness, 2010) and thus represents a particularly suitable model for our study. In research findings presented here, we track two robust mechanisms for transient stress response in plants: genomic DNA cytosine methylation (\% 5-mC) and heat shock protein 70 expression (HSP70). The methylation of 5cytosine $(\% 5-\mathrm{mC})$ occurs when a methyl group is enzymatically attached to the 5 ' carbon of

102 This reversible chemical modification elicits transient phenotypic changes required for stress 103 response, especially in plants (Meyer, 2008; Boyko and Kovalchuk, 2011; Arikan et al., 2018). 104 HSP70 chaperone protein is a well-characterized and universal stress responder that facilitates 105 refolding of denatured proteins, and thus restoration of vital metabolic activities (Walter and 106 Ron, 2011). 
We compared global DNA methylation $(\% 5-\mathrm{mC})$ in response to acute heat stress in two

\section{2- Materials and Methods}




\subsection{Water Collection and analyses}

139 Concentrations of dissolved oxygen (DO) were obtained using the Winkler titration method.

140 Oxygen was fixed on site using manganous sulfate, alkaline potassium iodide azide, and

141 sulfamic acid. Sodium thio- sulfate was used to titrate the water sample with starch indicator to a

142 clear endpoint.

\subsection{Collection of plant material and heat shock}

145 Sporobolus alterniflorus (formerly Spartina alterniflora) plants were removed from their native 146 environments in Harding Lagoon near Soundview Park, Bronx River estuary, NY (4048'35.6"N, $\left.147 \quad 73^{\circ} 34^{\prime} 18.0^{\prime \prime} \mathrm{W}\right)$, and at Todd's Point estuary in Greenwich Cove, CT (41 ${ }^{\circ}{ }^{\prime} 30.8088^{\prime \prime} \mathrm{N}$,

$\left.148 \quad 73^{\circ} 34^{\prime} 14.1709^{\prime \prime} \mathrm{W}\right)$. Plants were taken along with their roots, soil, and native water at low tide.

149 Plants were transported to the laboratory, where each plant was transplanted into native soil in a separate plastic cup with holes punched in the sides and base to allow for adequate aeration. All plants were equilibrated at approximately $23^{\circ} \mathrm{C}$ in a large basin of native water with aeration, for

152 at least 24 hours. For the initial heat shock, four individual plants from each were incubated in a 153 stand-up incubator at $42 \pm 2^{\circ} \mathrm{C}$ for 30 minutes in pre-heated native water, and the incubator was

154 left dark. Water was not aerated during treatment. Concurrently, four individual plants from each 155 site (8 total plants), were incubated in their respective water at room temperature $\left(21 \pm 1^{\circ} \mathrm{C}\right)$ for 30 minutes in the dark without aeration to serve as controls. After treatments, all plants were moved to room temperature (both air and native water), ambient light, with no aeration to rest for

15830 minutes. After resting, plants underwent a second treatment, heat shock or control, as 159 described above. Post second treatment, all plants were moved to room temperature air and native water and allowed to rest overnight in ambient light with aeration. Grass samples were collected over multiple years, at the same time of year, and on the same tides, and as such represent appropriate biological replicates.

\subsection{DNA extraction}

DNA was isolated using the Qiagen DNeasy Plant Mini Kit (Qiagen, \#69104). Leaves were cut matter was pooled and cut into small pieces with clean dissecting scissors and crushed with a 
mortar and pestle and $400 \mu \mathrm{L}$ AP1 (lysis buffer) + and $4 \mu \mathrm{L}$ RNase. All contents were transferred to a micro centrifuge tube. Pipetting up and down further agitated samples. Samples were vortexed and incubated in a heat block at $65^{\circ} \mathrm{C}$ for 10 minutes, vortexing 2-3 times during incubation. The remaining steps were performed according to the Qiagen DNeasy Plant Mini Kit. DNA concentrations and quality were assessed using Nano Drop Microvolume Spectrophotometer (ThermoFisher Scientific). DNA samples were stored at $-20^{\circ} \mathrm{C}$ in $\mathrm{AE}$ buffer from Qiagen DNeasy Plant Mini Kit.

\subsection{Global DNA methylation analysis}

Global genomic methylation levels were determined using $100 \mathrm{ng}$ of DNA for each sample using the MethylFlash Methylated DNA Quantification Kit Colorimetric (Epigentek, \#P-1034). The absolute methylation level was determined using a standard curve. The percentage of globally methylated DNA was calculated using absolute quantification from the Epigentek Protocol.

\subsection{Protein extraction and concentration determination}

Leaves were cut with clean dissecting scissors from near the stem of each individual plant and wiped clean of any dirt or debris. Plant tissue $(500 \mathrm{mg})$ was pooled from four individuals from each site/condition. Tissue was immediately placed into lysis bags provided in the P-PER Plant Protein Extraction Kit (Thermo Scientific, \#89803, Rockford, IL) and lysed according to provided instructions with the following modification: the volume of working solution was reduced to half of the recommended volume per sample. Protein solutions were stored at $-20{ }^{\circ} \mathrm{C}$ for no longer than 4 weeks. Concentrations of proteins in plant leaves were determined according to the Pierce BCA Protein Assay Kit-Reducing Agent Compatible (Thermo Scientific, \#23250, Rockford, IL).

\subsection{Quantification of heat shock protein}

Specific heat shock protein (HSP70) protein levels were quantified by Western blot (SDSPAGE) analysis. Plant leaf protein samples $(30-100 \mu \mathrm{g})$ were run on a 10\% Mini-PROTEAN ${ }^{\circledR}$ TGX ${ }^{\mathrm{TM}}$ Precast Protein Gel (Bio-Rad) and transferred to PVDF membranes, Ponceau stained to visualize protein transfer and evenly loaded across samples. Membranes were blocked for 1 hour at room temperature overnight at $4{ }^{\circ} \mathrm{C}$ in Superblock (Thermo-scientific, \#37535, Rockford, IL). 
200 After blocking, blots were incubated in mouse HSP70 monoclonal antibody (1:1000, Enzo,

201 \#AZI-SPA-820, Plymouth Meeting, PA). After washing 3x 10min in TBS + Tween20,

202 membranes were incubated in goat anti-mouse secondary antibody (1:10,000, Thermo-scientific,

203 \#31430, Rockford, IL) for 1 hour at room temperature. Membranes were washed 3 x 10min in

204 TBS + Tween 20 before proteins were detected by Immuno-Star luminol-peroxide (Bio-Rad,

205 \#170-5070). Bio-Rad Chemi-doc was used to visualize and quantify proteins with densitometry.

2.7 DNA barcoding

208 DNA isolated from 12 organisms from each site (described above) was used to PCR amplify the 209 universal plant gene $r b c L$ using the following primers:

210 rbcLaF 5' - TGTAAAACGACGGCCAGTATGTCACCACAAACAGAGACTAAAGC-3’

211 rbcLa rev 5'CAGGAAACAGCTATGACGTAAAATCAAGTCCACCRCG-3'

212 Primers were a generous gift from the DNA Learning Center, Harlem, NY. PCR reactions were

213 performed using GE illustra PURETaq Ready-To-Go PCR beads, $25 \mu \mathrm{L}$ of PCR reaction, $2 \mu \mathrm{L}$ of

214 template DNA, and $11.5 \mu \mathrm{L}$ of primers. Reactions were run for 50 cycles: 30 seconds

215 denaturation at $94^{\circ} \mathrm{C}, 45$ seconds annealing at $54^{\circ} \mathrm{C}$, and 45 seconds extending $72^{\circ} \mathrm{C}$ using

216 Techne Genius Thermal Cycler. PCR amplicons were visualized on a 2\% agarose gel using

217 pBR322/BstNI molecular weight standards to ensure that products were the predicted size. PCR

218 products were sent to Genewiz Inc. for sequencing. Sequences were aligned using Nucleotide

219 BLAST. Percent similarity was ascertained using the CLUSTAL W (Thompson et al., 1994; Ni

220 et al., 2012).

221

\section{$222 \quad 2.8$ Statistical analysis}

223 All water analysis data are presented as mean \pm SD. $\mathrm{p}<0.0001$ for dissolved oxygen

224 concentrations, $\mathrm{p}=0.0063$ for $\mathrm{pH}$ values. Error bars and error ranges display \pm S.E.M. as in Table

2251 and Figure 2 respectively. P-values were determined through unpaired t-tests for statistical

226 comparisons of two discrete populations as in Table 1. ANOVA tests for statistical comparisons

227 of more than two experimental groups and/or discrete populations were performed as in Figure 2.

228 P-values less than or equal to 0.05 are assumed to display statistical significance. 


\subsection{Water analyses}

233 Over a 9-year survey of the waters in the Bronx River estuary versus its less impacted

234 counterpart in Greenwich Cove estuary, we collected physicochemical data regarding $\mathrm{pH}$,

235 temperature and dissolved oxygen levels. As shown in Table 1, the temperature and $\mathrm{pH}$ of the

236 two sites are comparable. Temperature and $\mathrm{pH}$ for Bronx River estuary are $21.93 \pm 1.05{ }^{\circ} \mathrm{C}$ and

$2377.28 \pm 0.05$, while Greenwich Cove estuary are $24.62 \pm 0.807{ }^{\circ} \mathrm{C}$ and $7.89 \pm 0.024$. However,

238 dissolved oxygen concentrations at the two sites consistently vary widely, with the Bronx River

239 estuary at $5.89 \pm 0.30 \mathrm{mg} / \mathrm{L}$ and Greenwich Cove estuary at $9.69 \pm 2.2 \mathrm{mg} / \mathrm{L}$. This difference is

240 statistically significant $(\mathrm{p}<0.0001)$. The National Oceanic and Atmospheric Administration

241 (NOAA) National Estuarine Eutrophication Survey classifies water quality falling between 2 and

$2425 \mathrm{mg} / \mathrm{L}$ dissolved oxygen as stressed (Bricker et al., 1999). These data indicate that organisms

243 residing in the Bronx River estuary are exposed to chronic, low oxygen levels, a condition that

244 induces stress and metabolic dysfunction (Halem, et al., 2014; Ravaschiere et al., 2017).

\begin{tabular}{|l|l|l|l|}
\hline Site & Dissolved $\mathrm{O}_{2}(\mathrm{mg} / \mathrm{L})$ & Temperature $\left({ }^{\circ} \mathrm{C}\right)$ & $\mathrm{pH}$ \\
\hline Bronx River & $5.59 \pm .302$ & $21.93 \pm 1.05$ & $7.28 \pm 0.05$ \\
\hline Greenwich Cove & $9.10 \pm .492$ & $24.62 \pm .807$ & $7.89 \pm .024$ \\
\hline
\end{tabular}

245

246

247

248

249

250

251

252

253

254

255

256

257

258

259

Table 1. Estuarian water metrics. Average levels of dissolved oxygen (DO) over a 9-year survey, water temperature over a 7-year survey, and pH over a 5-year survey of the Bronx River estuary, NY and Greenwich Cove, CT. All water collections occurred in June and July, around low tide. Data are presented as mean \pm SD. $p<0.0001$ for dissolved oxygen concentrations, $\mathrm{p}=0.0063$ for $\mathrm{pH}$ values.

\subsection{Global methylation in response to stress for grasses from the differentially impacts sites}

As shown in Figure 2, acute heat stress, as monitored by heat shock protein levels, results in inverse global DNA methylation profiles when comparing grasses collected from sites with distinctly different levels of environmental challenge. Percent global DNA methylation is increased by heat shock for grasses from the Bronx River estuary but is decreased by heat shock for Greenwich Cove organisms. These results are statistically significant ( $p$ values $<0.05$ ). Interestingly, Bronx River grasses consistently demonstrate lower baseline global methylation levels as compared with their Greenwich Cove conspecifics (in Figure 1, compare Bronx and Greenwich controls). 
Percent Global Methylation Across Sites and Treatments

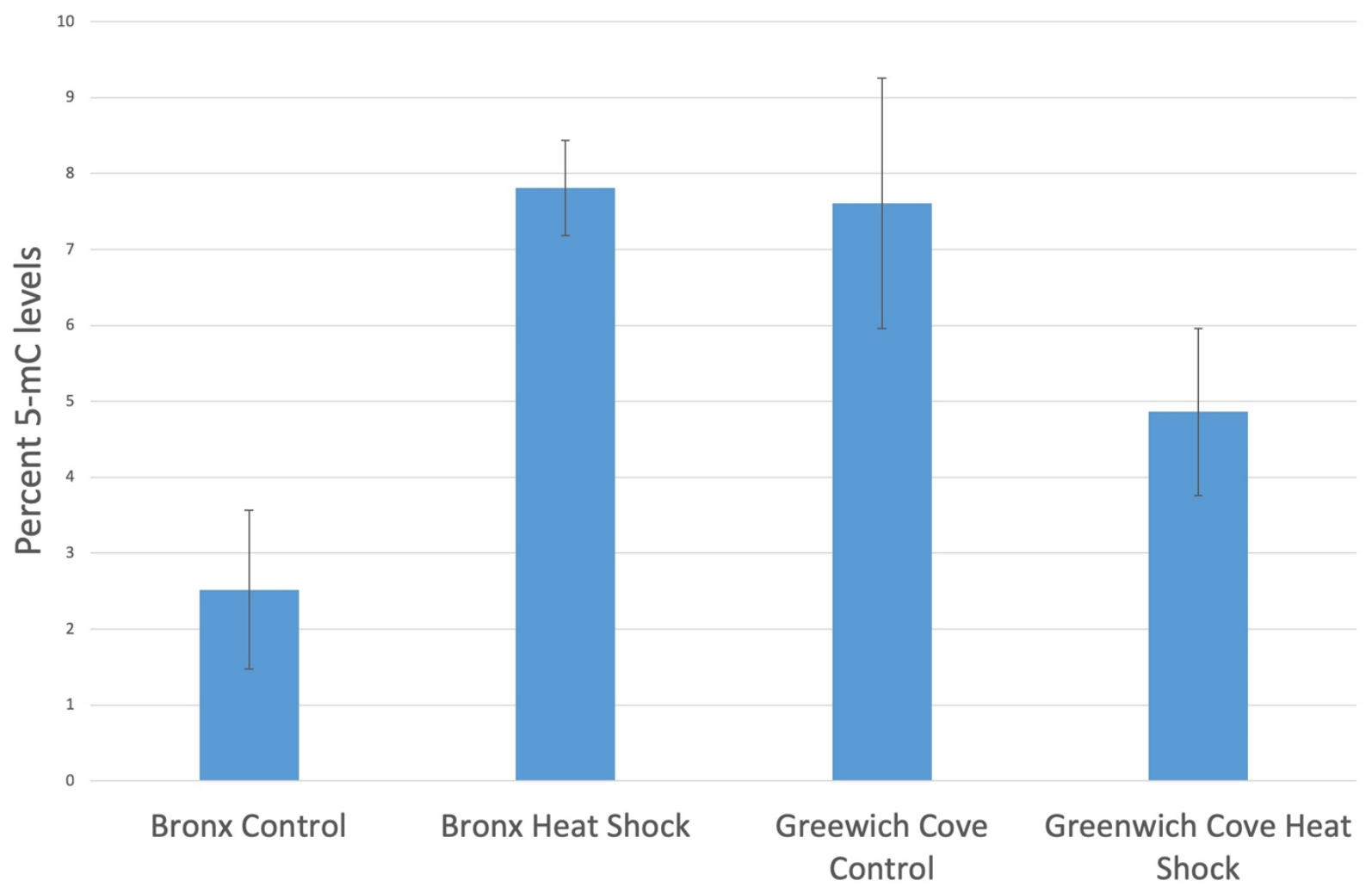

Site and Treatment

Figure 1: Quantification of global DNA methylation over two years. Average percent 5-methlycytosine (5-mC) of $S$. alterniflorus from the Bronx River and Greenwich Cove estuaries ( $\mathrm{n}=4$ for each group). The two populations launch inverse methylation responses in acute heat stress. Bronx individuals increase global methylation $(\mathrm{p}<0.05)$, while Greenwich Cove individuals decrease global methylation, $(\mathrm{p}<0.05)$. Statistical results are based on ANOVA tests.

268 Western blots analyses of heat shock immuno-reactive proteins bands (HSP70) across two years

269 (Figure 2) show that heat shock proteins were successfully elicited in controlled laboratory

270 settings in grasses from both sites. 

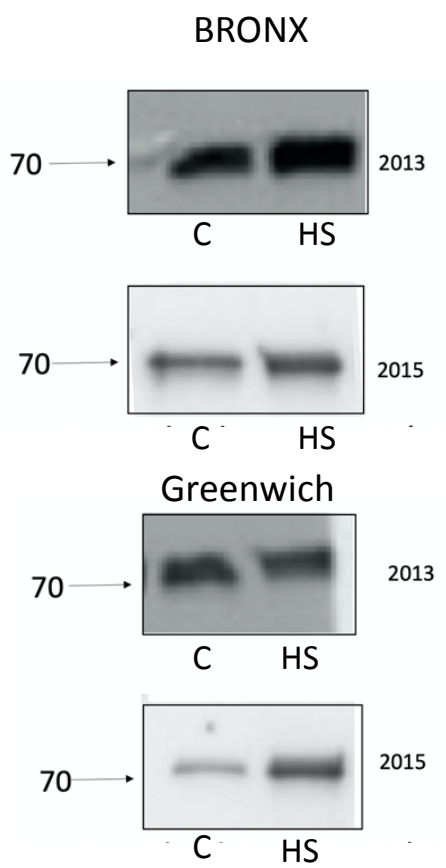

Figure 2: HSP70 Western blot analyses, S. alterniflorus (2013 and 2015), collected from Bronx River Estuary (top) and Greenwich Cove (bottom). Arrows point to $70 \mathrm{kDa}$ HSP70 immunoreactive band. $\mathrm{C}=$ control and $\mathrm{HS}=$ heat shocked.

\subsection{Barcoding for species identification}

277 Among $r b c L$ chloroplast DNA gene sequences derived from individuals native to both the Bronx

278 River and Greenwich Cove, CLUSTAL W alignment revealed negligible heterogeneity (0 - 1\%).

279 In addition, CLUSTAL W alignment also showed insignificant ( 0 - 1\%) divergence in $r b c L$

280 sequence within both populations. These results indicate that all specimens used in this study

281 from both sites are members of the same species, either Sporobolus alterniflorus or Sporobolus

282 maritimus. Based on geographical data Sporobolus maritimus is not native to the Bronx or

283 Connecticut (USDA, plants database). Thus, we determined that Sporobolus alterniflorus is the

284 species we analyzed at both sites, Greenwich Cove and Bronx River estuaries.

\section{4- Discussion}

Rapid global urbanization and its impact on the environment are fundamentally changing

288 the course of evolution in organisms that represent our urban co-inhabitants (Hendry and 
Kinnison, 1999; Alberti, 2015; Donihue and Lambert, 2015; Johnson and Munshi-South, 2017). Plant life is critical to sustainable development of urban ecosystems (Barbier et al., 2011; Mexia et al., 2018). Thus, an important challenge in ecology is to gain a fuller understanding of the mechanisms by which plants cope with current unprecedented rates of environmental change.

293 Information presented here contributes to a growing field of research that documents key molecular mechanisms by which plants adapt to the challenges of urbanization.

Studies that focus specifically on wild populations native to urban landscapes are especially well suited for predicting and conserving life in urban ecosystems. To date, few studies employ in vivo techniques to analyze the mechanisms of stress tolerance in wild populations as they respond to urbanization in their native habitats (Thiebau et al., 2019). For this study, two distinct wild populations of estuarine grasses were chosen as the biological models. Sporobolus alterniflorus was collected from two sites: the Bronx River, NY and Greenwich Cove, CT. These estuaries are located along an urban to suburban gradient, that features differential degrees of urbanization both quantitatively and historically (Rachlin et al., 2007; Halem et al., 2014; Ravaschiere et al., 2017). Physio-chemical analyses of estuary water, presented in Table 1, demonstrate that the Bronx River estuary consistently experiences long term, comparatively low dissolved oxygen, and these results are statistically significant. Hypoxic conditions in the Bronx River are associated with chronic stress response and metabolic disruptions in a foundation molluscan species (Halem, et al., 2014; Ravaschiere et al., 2017). Low dissolved oxygen primarily results from phosphorus and nitrogen run-off associated with wastewater and urban run-off. In addition, gas exchange in Sporobolus alterniflorus relies on direct access to dissolved oxygen from the aquatic environment via stems and roots that are often tidally submerged. These submerged parts of the plant, exposed to chronically low dissolved oxygen, must fulfill respiratory needs for the entire plant (Teal and Kanwisher, 1966). Thus, a low dissolved oxygen concentration directly inhibits vital metabolic processes and serves as a predictable indicator for urbanization and contamination. 
320 heat shock was applied and induction of heat shock protein was confirmed by Western Blot analyses, we quantified changing levels of \% 5-mC DNA methylation. This allowed us to monitor epigenetic modification as a response to acute stress in two differentially impacted plant populations. Figure 1 demonstrates that the Bronx River and Greenwich Cove grasses exhibited statistically different inverse DNA methylation profiles in response to the controlled application of acute heat stress. Western Blot analyses (Figure 2) confirm heat stress as indicated by the predicted and significant increases in heat shock protein (molecular weight $70 \mathrm{kD}$ ), and this response was documented across two years.

Results of our global DNA methylation analyses suggest that the two distinct populations of grasses counter the same heat stress by eliciting DNA methylation profiles that differ fundamentally and in biologically relevant ways. Our results show that grasses from the Bronx River estuary counter an acute stress via DNA hyper-methylation. Further studies are necessary to confirm our speculation that hyper-methylation may be an essential metabolic trade-off that globally shuts down gene expression, sparing only the basic housekeeping functions that are necessary for survival during acute stress. Whereas, for grasses native to the less impacted Greenwich Cove, application of acute stress elicits a reverse pattern, a hypo-methylation of the genome that may facilitate expression of those loci required for a successful acute stress response. In support of our findings, multiple recent studies demonstrate that individual plant populations counter similar environmental stressors in different ways, and this may be controlled at the epigenetic level (Saez- Laguna et al., 2014; Thiebaut et al., 2019; Rehman and Tanti, 2020). from these two geographically distinct populations have negligible differences in chloroplast $r b c L$ gene sequence (Kress and Erikson, 2007). Very low rate of sequence divergence (1\% or less) between individuals from the Bronx River and Greenwich Cove estuaries indicates that these individuals belong to the same species and are thus genetically identical. Differential DNA

The inverse epigenetic profiling that we report here between Bronx and Greenwich Cove grasses do not result from speciation. Our barcoding results demonstrate that grasses collected methylation within a species is now recognized as a critical indicator of short-term ecological experience (Rey et al., 2020). This notion of “ecological populations" will become essential in conservation biology with the recognition that epigenetics offers a key link between environmental change and phenotypic plasticity in wild populations (Rey et al., 2020). 
Enhanced tolerance to stress could provide an evolutionary advantage for Bronx River grasses when confronted with the unpredictable challenges inherent to their native habitat. A phenomenon called defense priming conditions plants to better tolerate abiotic stressors, and this constitutes an important evolutionary benefit (Matinez-Medina et al., 2011; Crisp et al., 2016).

355 This switch-like and reversible process offers sufficient genomic flexibility for sessile organisms, like plants, to respond rapidly to fluctuating environmental challenges (Meyer, 2008; Boyko and Kovalchuk, 2011; Arikan et al., 2018). Evidence suggests that defense priming improves fitness (Conrath et al., 2006; Matinez-Medina et al., 2011), and is regulated by epigenetic modification (Luna et al., 2012). In defense priming, a "stimulus" targets individual loci such that their methylation states become altered. This affects future accessibility of transcriptional machinery and gene expression eliciting a rapid and sustained response upon a later "triggering stimulus". We hypothesize that long term hypoxia, as well as potential additional environmental challenges at the urbanized Bronx River estuary, constitute the priming "stimulus" for this particular population of grasses. Chromatin restructuring, specifically changes to DNA methylation patterns, is a mechanism by which plants engage in defense priming (Conrath et al., 2015; Savvides et al., 2016; Pastor et al., 2013), and here we demonstrate that two distinct plant populations deploy inverse patterns of global DNA methylation when encountering the same acute stressor. These results suggest that grasses from the Bronx River Estuary may be engaged in defense priming. Our research contributes to rapidly growing body of evidence demonstrating that successful strategies for coping with rapid environmental change do not rely solely on random heritable changes in DNA sequence. For sessile species such as plants, critical evolutionary adaptations are propelled by epigenetic change (Youngson et al., 2008; Holeski et al., 2012; Robertson et al., 2017; Thiebau et al., 2019; Whittle et al., 2019; Rey el al., 2020). change are based on the assumption that all members of a species elicit the same, or similar responses to an environmental stressor (Sih et al., 2011). However, data presented here corroborate growing evidence suggesting that populations separated geographically or by differential stressors indeed demonstrate key distinct coping mechanisms (Fossog et al., 2013; Halem et al., 2014; Ravaschiere et al., 2017; De Almeida Duarte et al., 2017). In other words, members of the same species may utilize diverging mechanisms in order to continue to thrive in the face of rapid and challenging environmental stressors. In addition, results presented here 
382

383

384

385

386

387

388

389

390

391

392

393

394

395

396

397

398

399

400

401

402

403

404

405

406

407

408

409

410

411

suggest that stress priming by epigenetic modification may enhance fitness in grasses native to the heavily impacted Bronx River estuary. These complex molecular mechanisms of biological adaptation deserve our attention so that we may better understand the ways in which particular populations develop unique adaptive responses that are specifically suited to unique ecological challenges.

As molecular ecologists and evolutionary biologists, we must accept the notion that environmentally induced adaptation is a key feature to sustaining resilience and biodiversity in rapidly expanding urban areas. As conservationists and urban planners, we must gain better understandings of the unique epigenetic mechanisms by which foundational, ecological service providers adapt and evolve to tolerate the pressures of urbanization. Future studies are required in order to identify genes that are differentially methylated in response to stress in Sporobolus alterniflorus, a species that is vital to urban sustainability. These studies await the full sequence analysis and annotation of the Sporobolus alterniflorus genome. In addition, future studies should be initiated to more fully understand the intricacies of adaptation in populations that remain chronically exposed to low oxygen and other stressors associated with urbanization.

\section{References}

Al-Whaibi, MH. Plant heat-shock proteins: a mini review. Journal of King Saud UniversityScience. 2011;23 (2): 139-150.

Alberti, M. Eco-evolutionary dynamics in an urbanizing planet. Trends Ecol Evol. 2015;30 (2): 114-126.

Anaraki ZE, Tafreshi SAH, Shariati M. Transient silencing of heat shock proteins showed remarkable roles for HSP70 during adaptation to stress in plants. Environmental and Experimental Botany. 2018;155: 142-157.

Angelos E, Ruberti C, Kim S-J, and Brandizzi F. Maintaining the factory: The roles of the unfolded protein response in cellular homeostatsis in plants. Plant Journal. 2016;90 (4): 671682.

Arikan B, Özden S, Turgut-Kara N. DNA methylation related gene expression and morphophysiological response to abiotic stresses in Arabidopsis thaliana. Environmental and Experimental Botany. 2018;149: 17-26. 
412 Arnholdt-Schmitt B. Stress-induced cell reprogramming. A role for global genome regulation?

413 Plant Physiology. 2004;136 (1): 2579-2586.

414 Astaraie-Imani M, Kapelan Z, Fu G, Butler D. Assessing the combined effects of urbanisation 415 and climate change on the river water quality in an integrated urban wastewater system in the 416 UK. J. Environ Manage. 2012;112: 1-9.

417 Barbier EB, Hacker S, Kennedy C, Koch E, Stier A, Silliman B. The value of estuarine and 418 coastal ecosystem services. Ecological Society of America. Ecological Monographs. 2011;81 419 (2): 169-193.

420 Bernes S, Siman-Tov R, Ankri S. Epigenetic and classical activation of Entamoeba histolytica 421 heat shock protein 100 (EHSP100) expression. FEBS Letters. 2005;579 (28): 6395-6402.

422 Bond DM, Baulcombe DC. Small RNAs and heritable epigenetic variation in plants. Trends in 423 Cell Biology. 2014;24 (2): 100-107.

424 Bossdorf O, Arcuri D, Richards C.L, Pigliucci M. Experimental alteration of DNA methylation affects the phenotypic plasticity of ecologically relevant traits in Arabidopsis thaliana. Evol.

426 Ecol. 2010;24: 541-553.

427 Boyko A, Kovalchuk I. Genome instability and epigenetic modification - heritable responses to 428 environmental stress. Current Opinion in Plant Biology. 2011;14: 260-266.

429 Bozaykut P, Ozer NK, Karademir B. Regulation of protein turnover by heat shock proteins. Free 430 Radical Biology and Medicine. 2014;77: 195-209.

431 Bricker S, Clement C, Pirhalla D, Orlando S, Farrow D. National Estuarine Eutrophication 432 Assessment. Effect of Nutrient Enrichment in the Nation's Estuaries. U.S. Department of 433 Commerce, National Oceanic and Atmospheric Administration. 1999.

434 Chin A, O’Dowd AP, Gregory KJ. Urbanization and River Channels. Treatise on 435 Geomorphology. Fluvial Geomorphology, San Diego: Academic Press. 2013;9: 809-827.

436 Chmura GL, Anisfeld SC, Cahoon DR, Lynch JC. Global carbon sequestration in tidal, saline 437 wetland soils. Advancing Earth and Space Science. Global Biogeochemical Cycles. 2003; 17 (4): 438 22(1-12).

439 Conrath U, Beckers GJ, Flors V, Garcia-Augustin P, Jakab G, Mauch F, et al. Priming: getting 440 ready for battle. Mol. Plant Microbe Interact. 2006;19 (10): 1062-1071.

441 Conrath U, Beckers GJM, Langenbach CJG, Jaskiewicz MR. Priming for enhanced defense. 442 Annual Review of Phytopathology. 2015;53: 97-119. 
Courrat A, Lobry J, Nicolas D, Laffargue P, Amara R, Lepage M, et al. Anthropogenic disturbance on nursery function of estuarine areas for marine species. Estuar Coast Shelf Science. 2009;81: 179-190.

Crimmens T, Larson M. Bronx River Alliance: Ecological Restoration and Management Plan. 2006. Available from: https://www.nycgovparks.org/download/bronx-river-ecologicalrestoration-and-management-plan-2006.pdf

Crisp PA, Ganguly D, Eichten SR, Borevitz J, Pogson BJ. Reconsidering plant memory: Intersections between stress recovery, RNA turnover, and epigenetics. Science Advances. 2016;2 e1501340: 1-14.

De Almeida Duarte LF, de Souza CA, Pereira CDS, Pinheiro MAA. Metal toxicity assessment by sentinel species of mangroves: In situ case study integrating chemical and biomarkers analyses. Ecotoxicology and Environmental Safety. 2017;145: 367-376.

De Jong L, Moreau X, Thiéry A. Expression of heat shock proteins as biomarker tool in aquatic invertebrates: actual knowledge and ongoing developments for the early detection of environmental changes and ecological risks. Heat-Shock Proteins: International Research. F. Columbus (Ed), Nova Science Publishers. 2008;20: 375-392.

Donihue MC, Lambert MR. Adaptive evolution in urban ecosystems. AMBIO. 2015;44: 194203.

461 Duarte IA, Reis-Santos P, França S, Cabral H, Fonseca VF. Biomarker responses to 462 environmental contamination in estuaries: A comparative multi-taxa approach. Aquatic 463 Toxicology. 2017;189: 31-41.

464 Feder ME, Hofmann GE. Heat-shock proteins, molecular chaperones, and the stress response: 465 evolutionary and ecological physiology. Annual Review of Physiology. 1999;61 (1): 243-282. HSP70 - a master regulator in protein degradation. FEBS Lett. 2017;591(17): 2648-60.

Fossog BT, Antonio-Nkondjio C, Kengne P, Njiokou F, Besansky NJ, Costantini C. Physiological correlates of ecological divergence along an urbanization gradient: differential tolerance to ammonia among molecular forms of the malaria mosquito Anopheles gambiae. BMC Ecology. 2013;13: 1. 
Gao WW, Xiao RQ, Peng BL, Xu HT, Shen HF, Huang MF, et al. Arginine methylation of HSP70 regulates retinoid acid-mediated RARbeta 2 gene activation. Proc. Natl. Acad. Sci. USA, 2015;112 (26): E3327-36.

Gedan KB, Bertness MD. Experimental warming causes rapid loss of plant diversity in New England salt marshes. Ecology Letters. 2009;12 (8): 842-848.

483 Gedan KB, Bertness MD. How will warming affect the salt marsh foundation species Spartina patens and its ecological role? Oecologia. 2010;164 (2): 479-487.

$485 \mathrm{Gu}$ X, Sun J, Li S, Wu X, Li L. Oxidative stress induces DNA demethylation and histone 486 acetylation in SH-SY5Y cells: potential epigenetic mechanisms in gene transcription in A $\beta$ 487 production. Neurobiology of Aging. 2013;34 (4): 1069-1079.

488 Guy CL, Li QB. The organization and evolution of the spinach stress 70 molecular chaperone 489 gene family. The Plant Cell. 1998;10 (4): 539-556.

490 Halem ZM, Ross DJ, Cox RL. Evidence for intraspecific endocrine disruption of Geukensia demissa (Atlantic ribbed mussel) in an urban watershed. Comparative Biochemistry and Physiology Part A: Molecular \& Integrative Physiology. 2014;175: 1-6. and molecular mechanisms of heat stress tolerance in plants. International Journal of Molecular Sciences. 2013;14 (5): 9643-9684.

Hasanuzzaman M, Nahar K, Fujita M. Plant response to salt stress and role of exogenous protectants to mitigate salt-induced damages. Ecophysiology and responses of plants under salt stress. Springer. 2013; 25-87.

499 Hauser MT, Aufsatz W, Jonak C, Luschnig C. Transgenerational epigenetic inheritance in plants. 500 Biochim. Biophys. Acta. 2011;1809 (8): 459-468.

501 He Y, Li Z. Epigenetic Environmental Memories in Plants: Establishment, Maintenance, and 502 Reprogramming. Trends in Genetics. 2018;34 (11): 856-866.

503 Hendershot LM. The ER function BiP is a master regulator of ER function. Mt Sinai J. Med. 504 2004;71 (5): 289-297.

505 Hendrick JP, Hartl FU. The role of molecular chaperones in protein folding. FASEB J. 1995;9

506 (15): 1559-1569.

507 Hendry AP, Kinnison MT. The pace of modern life: measuring rates of contemporary 508 microevolution. Evolution. 1999;53: 1637-1653.

509 Holeski LM, Jander G, Agrawal AA. Transgenerational defense induction and epigenetic

510 inheritance in plants. Trends in Ecology and Evolution. 2012;27 (11): 1-9. 
511 Johnson MT, Munshi-South J. Evolution of life in urban environments. Science. 2017;358

512 (6363): Eaam8327.

513 Jones C, Lawton J, Shachak M. Positive and negative effects of organisms as physical ecosystem

514 engineers. Ecology. 1997;78: 1946-1957.

515 Kovalchuk I, Abramov V, Pogribny I, Kovalchuk O. Molecular aspects of plant adaptation to life 516 in the Chernobyl zone. Plant Physiology. 2004;135: 357-363.

517 Kress W, Erikson D. A two-locus global DNA barcode for land plants: the coding $r b c L$ gene 518 complements the non-coding trnH-psbA spacer region. PLoS One. 2007;2(6): e508.

519 Lämke J, Bäurle I. Epigenetic and chromatin-based mechanisms in environmental stress

520 adaptation and stress memory in plants. Genome biology. 2017;18 (1): 124.

521 Leborgne-Castel N, Jelitto-Van Dooren EP, Frofts AJ, Denecke J. Overexpression of BiP in

522 tobacco alleviates endoplasmic reticulum stress. Plant Cell. 1999;11 (3): 459-470.

523 Limburg KE, Stainbrook KM. Urbanization consequences: Case studies in the Hudson River 524 watershed. American Fisheries Society Symposium. 2005;23-37.

525 Litten S, Fowler B, Gauthier M, Bloom N. Contaminant Assessment and Reduction Project

526 (CARP): Toxic Chemicals in New York Harbor and Vicinity - Sources and Ambient

527 Concentrations of Pesticides, PAHs, Mercury, and Cadmium. 2007. Available from:

528 http://www.dec.ny.gov/docs/water_pdf/organicmetalposter.pdf

529 Lira-Medeiros CF, Parisod C, Fernandes RA, Mata CS, Cardoso MA, Ferreira PCG. Epigenetic 530 variation in mangrove plants occurring in contrasting natural environments, PLoS One. 2010;5 531 (4): 10326.

532 Liu D, Zhang X, Cheng Y, Takano T, Liu S. rHSP90 gene expression in response to several 533 environmental stresses in rice (Oryza sativa L.). Plant Physiol. Biochem. 2006;44 (5): 380-386.

534 Lotze HK, Lenihan HS, Bourque B, Bradbury RH. Depletion, Degradation, and Recovery 535 Potential of Estuaries and Coastal Seas. Science. 2006;312 (5781): 1806-1809.

536 Luna E, Bruce TJA, Roberts MR, Flors V, Ton J. Next-generation systemic acquired resistance. 537 Plant Physiol. 2012;158: 844-853.

538 Martinez-Medina A, Flors V, Heil M, Mauch-Mani B, Pieterse C, Pozo MJ, et al. Recognizing 539 Plant Defense Priming. Trends in Plant Science. 2016;21 (10): 818-822.

540 McFarlin CR, Bishop TD, Hester MW, Alber M. Context-dependent effects of the loss of 541 Spartina alterniflora on salt marsh invertebrate communities. Estuarine, Coastal and Shelf 542 Science. 2015;163 (Part B): 218-230. 
543 Mexia T, Vieira J, Principe A, Anjos A, Silva P, Lopes N, et al. Ecosystem services: Urban parks 544 under a magnifying glass. Environmental Research. 2018;160: 469-478.

545 Molinier J, Ries G, Zipfel C, Hohn B. Transgeneration memory of stress in plants. Nature. 546 2006;442 (7106): 1046-1049.

547 Negi P, Rai AN, Suprasanna P. Moving through the Stressed Genome: Emerging Regulatory 548 Roles for Transposons in Plant Stress Response. Frontiers in Plant Science. Plant Genetics and 549 Genomics, Plant Translational Research in the Genomics Era. 2016;7 (1448): 1-20.

550 Nelson K, Palmer M, Pizzuto J, Moglem G, Angermeier P, Hilderbrand R, et al. Forecasting the 551 combined effects of urbanization and climate change on stream ecosystems: from impacts to 552 management options. J. Applied Ecology. 2009;46: 154-163.

553 Noh SJ, Kwon CS, Oh DH, Moon JS, Chung WI. Expression of an evolutionarily distinct novel 554 BiP gene during the unfolded protein response in Arabidopsis thaliana. Elsevier. Gene. 2003; 555 81-91.

556 Nover L, Scharf KD, Gagliardi D, Vergne P, Czarnecka-Verner E, Gurley WB. The Hsf world: 557 classification and properties of plant heat stress transcription factors. Cell Stress Chaperones.

558 1996;1 (4): 215-223.

559 Pastor V, Diez EL, Mauch-Mani B, Ton J. Primed plants do not forget. Environ. Exp. Bot. 560 2013;94: 46-56.

561 Popova OV, Dinh HQ, Aufsatz W, Jonak C. The RdDM pathway is required for basal heat 562 tolerance in arabidopsis. Molecular Plant. 2013;6 (2): 396-410.

563 Peterson PM, Romaschenko K, Arrieta YH, Saarela JM. (2332) Proposal to conserve the name 564 Sporobolus against Spartina, Crypsis, Ponceletia, and Heleochloa (Poaceae: Chloridoideae: 565 Sporobolinae). TAXON. 2014;63 (6): 1373-1374.

566 Rachlin JW, Warkentine BE, Pappantoniou A. An Evaluation of the Ichthyofauna of the Bronx 567 River, a Resilient Urban Waterway. Albany, NY: Northeastern Naturalist. 2007;14: 531-544.

568 Ravaschiere A, Cutler C, Edleson K, Halem Z, Magun H, Meckler F, et al. Quantification of 569 Heat Shock Protein 70 and Acetylcholinesterase Over a Time Course Suggests Environmental 570 Adaptation in a Foundational Molluscan Species. Ecotoxicology and Environmental Safety. 571 2017;142: 222-229.

572 Redfield A. Development of a New England salt marsh. Ecol. Monograph. 1972;42: 201-237.

573 Rehman, Tanti. Understanding epigenetic modifications in response to abiotic stresses in plants. 574 Biocatalysis and Agricultural Biotechnology. 2020;27: 101673. 
575 Rejeb IB, Pastor V, Mauch-Mani B. Plant responses to simultaneous biotic and abiotic stress:

576 molecular mechanisms. Plants. 2014;3 (4): 458-475.

577 Rey O, Danchin E, Mirouze M, Loot C, Blanchet S. Adaptation to Global Change: a transposable

578 element - epigeneticsperspective. Trends in Ecology and Evolution. 2016;31 (7): 514-526.

579 Rey O, Eizaguirre C, Angers B, Baltazar-Soares M, Sagonas K, Prunier J, et al. Linking

580 epigenetics and biological conservation: Toward a conservation epigenetics perspective.

581 Functional Ecology. 2020;34: 414-427.

582 Robertson M, Schrey A, Moss CJ, Richards C. Genetic and epigenetic variation in Spartina

583 alterniflora following the Deepwater Horizon oil spill. Evol. Applications. 2017;1-10: 792-801.

584 Saez-Laguna E, Guevara MA, Diaz LM, Sanchez-Gomez D, Collada C, Aranda I, et al.

585 Epigenetic Variability in the Genetically Uniform Forest Tree Species Pinus pinea L. PLoS One.

$586 \quad 2014 ; 9$ (8): e103145.

587 Sanders BM, Hope C, Pascoe VM, Martin LS. Characterization of the stress protein response in 588 two species of Collisella limpets with different temperature tolerances. Physiological Zoology.

589 1991; 1471-1489.

590 Savvides A, Ali S, Tester M, Fotopoulos V. Chemical priming of plants against multiple abiotic 591 stresses: mission possible? Trends in Plant Science. 2016;21 (4): 329-340.

592 Seto KC, Sánchez-Rodríguez R, Fragkias M. The new geography of contemporary urbanization 593 and the environment. Annual Review of Environment and Resources. 2010;35: 167-194.

594 Scarpaci TE, Zanor MI, Valle EM. Investigating the role of plant heat shock proteins during 595 oxidative stress. Plant Signaling \& Behavior. 2008;3 (10): 856-857.

596 Schlesinger MD, Manley PN, Holyoak M. Distinguishing stressors acting on land bird

597 communities in an urbanizing environment. Ecology. 2008;89 (8): 2302-2314.

598 Schlesinger MJ. Heat shock proteins. J. Biol Chem. 1990;265 (21): 12111-12114.

599 Schröder M, Kaufman RJ. ER stress and the unfolded protein response. Mutation

600 Research/Fundamental and Molecular Mechanisms of Mutagenesis. 2005;569 (1-2): 29-63.

601 Sih, Ferrari, Harris. Evolution and behavioural responses to human-induced rapid environmental 602 change. Evolutionary Applications. 2011;4(2): 367-387.

603 Shibahara T, Kawasaki H, Hirano H. Identification of the 19S regulatory particle subunits from 604 the rice 26S proteasome. FEBS Journal. 2002;269 (5): 1474-1483. 

elements between biotic and abiotic components of terrestrial ecosystem along an urbanization gradient: Soil, leaf litter and ground beetles. Ecological Indicators. 2016;60: 258-264.

Slattery HR. Urbanization: impact on dissolved oxygen and sedimentation in the hart brook watershed (Lewiston, Maine). Honors Theses 2018; 243. Available from: https://scarab.bates.edu/honorstheses/243/

611 Smirnoff N. Plant resistance to environmental stress. Curr. Opin. Biotechnol. 1998;9 (2): 214612219.

613 Sung DY, Kaplan F, Guy CL. Plant HSP70 molecular chaperones: protein structure, gene family, 614 expression and function. Physiologia Plantarum. 2002;113 (4): 443-451.

615 Teal J, Kanwisher J. Gas transport in the marsh grass, Spartina alterniflora. J. Experimental 616 Botany. 1966;17(51): 355-361.

617 Tedeschi JN, Kennington WJ, Berry O, Whiting S, Meekan M, Mitchell NJ. Increased 618 expression of HSP70 and HSP90 mRNA as biomarkers of thermal stress in loggerhead turtle 619 embryos (Caretta Caretta). J. Therm. Biol. 2015;47: 42-50.

620 Thompson JD, Higgins DG, Gibson TJ. CLUSTAL W: improving the sensitivity of progressive 621 multiple sequence alignment through sequence weighting, position-specific gap penalties and 622 weight matrix choice. Nucleic Acids Res. 1994;11 22(22): 4673-4680.

623 Thiebaut F, Hemerly AS, Ferreira PCG. A Role for Epigenetic Regulation in the Adaptation and 624 Stress Responses of Non-model Plants. Front. Plant Sci. 2019;10 (246): 1-7.

625 Van Dolah RF, Riekerk GH, Bergguist DC, Felber J, Chestnut DE, Holland AF. Estuarine 626 habitat quality reflects urbanization at large spatial scales in South Carolina's coastal zone. Sci. 627 Total Environ. 2008;390 (1): 142-154.

628 Van Loon-Steensma JM, Vellinga P. Trade-offs between biodiversity and flood protection 629 services of coastal salt marshes. Current Opinion in Environmental Sustainability. 2013;5 (3-4): $630 \quad 320-326$.

631 Walter P, Ron D. The unfolded protein response: from stress pathway to homeostatic regulation. 632 Science. 2011;334 (6059): 1081-1086.

633 Wang C, Gu X, Wang X, Guo H, Geng J, Yu H, et al. Stress response and potential biomarkers 634 in spinach (Spinacia oleracea L.) seedlings exposed to soil lead. Ecotoxicol. Environ. Saf. $635 \quad 2011 ; 74(1): 41-47$.

636 Wang J, Pant HK. Enzymatic hydrolysis of organic phosphorus in river bed sediments. 637 Ecological Engineering. 2010;36 (7): 963-968. 
638 Wang W, Vinocour B, Shoseyov O, Altman A. Role of plant heat-shock proteins and molecular 639 chaperones in the abiotic stress response. Trends in Plant Science. 2004;9 (5): 244-252.

640 Wang WS, Pan YJ, Zhao XQ, Dwivedi D, Zhu LH, Ali J, et al. Drought-induced site-specific 641 DNA methylation and its association with drought tolerance in rice (Oryza sativa L.). J. Exp.

642 Bot. 2011;62 (6): 1951-1960.

643 Wang WX, Vinocur B, Altman A. Plant responses to drought, salinity and extreme temperatures:

644 towards genetic engineering for stress tolerance. Planta. 2003;218 (1): 1-14.

645 Wang Y, Reiter RJ, Chan Z. Phytomelatonin: a universal abiotic stress regulator. J. Exp. Botany. $646 \quad 2018 ; 69(5): 963-974$.

647 Whittle CA, Otto SP, Johnston MO, Krochko JE. Adaptive epigenetic memory of ancestral 648 temperature regime in Arabidopsis thaliana. Botany. 2009;87: 650-657.

649 United States Department of Agriculture (USDA), Plants Database. Available from:

650 https://plants.usda.gov/core/profile?symbol=SPAL https://plants.usda.gov/core/profile?symbol=SPMA6

651 Youngson NA, Whitelaw E. Transgenerational epigenetic effects. Ann. Rev. Genomics Hum.

652 Genet. 2008;9: 233-257. 